\title{
Foresight for income and employment: What can we learn for agricultural research for development
}

\author{
Gideon Kruseman, Ahmad Dermawan, Mandiaye Diagne, Dolapo Enahoro, Aymen Frija, Marcel \\ Gatto, Sika Gbegbelegbe, Adam Komarek, Kai Mausch, Khondoker Mottaleb, Swamikannu \\ Nedumaran, Kindie Tesfaye, Harold Glenn Valera
}

\section{CGIAR Foresight}

Strategic foresight and modeling to support food systems decision making. 



\title{
Foresight for income and employment: What can we learn for agricultural research for development
}

\author{
Gideon Kruseman ${ }^{1 *}$, Ahmad Dermawan², Mandiaye Diagne ${ }^{3}$, Dolapo Enahoro ${ }^{4}$, Aymen Frija ${ }^{5}$, \\ Marcel Gatto ${ }^{6}$, Sika Gbegbelegbe ${ }^{7}$, Adam Komarek ${ }^{8}$, Kai Mausch ${ }^{9}$, Khondoker Mottaleb, \\ Swamikannu Nedumaran ${ }^{10}$, Kindie Tesfaye ${ }^{1}$, Harold Glenn Valera ${ }^{11}$
}

December 22, 2021

\author{
${ }^{1}$ International Maize and Wheat Improvement Center (CIMMYT) \\ ${ }^{2}$ Center for International Forestry Research (CIFOR) \\ ${ }^{3}$ Africa Rice Center (AfricaRice) \\ ${ }^{4}$ International Livestock Research Institute (ILRI) \\ ${ }^{5}$ International Center for Agricultural Research in the Dry Areas (ICARDA) \\ ${ }^{6}$ International Potato Center \\ ${ }^{7}$ International Institute of Tropical Agriculture (IITA)
}

${ }^{8}$ The University of Queensland, School of Agriculture and Food Sciences, formerly International Food Policy Research Institute (IFPRI)

${ }^{9}$ Center for International Forestry Research (CIFOR)-World Agroforestry (ICRAF)

10 International Crops Research Institute for the Semi-Arid Tropics (ICRISAT)

${ }^{11}$ International Rice Research Institute (IRRI)

* corresponding author: g.kruseman@cgiar.org

This document is one of a collection of three working papers and a synthesis brief edited by Steven Prager and Keith Wiebe, and prepared as part of foresight-related research supported by the CGIAR Research Program on Policies, Institutions, and Markets. These working papers are intended to provide a forwardlooking perspective on key issues to support discussion on food, land, and water systems transformation. We are grateful to members of a steering committee (Stephan Weise, Frank Place, Marianne Bänziger, Vincent Gitz, Oscar Ortiz, Michael Phillips, Tom Randolph, May-Guri Saethre, and Mark Smith) for their guidance, as well as to several anonymous reviewers for their comments on an earlier draft.

These working papers and the synthesis brief will be made available at http://foresight.cgiar.org. 


\section{Abstract}

Challenges related to poverty, hunger, nutrition, health, and the environment are widespread and urgent. One way to stress the urgency of making the right decisions about the future of the global food systems now is to better understand and more clearly articulate the alternative scenarios that food systems face. Developing, synthesizing, and presenting such alternatives to decision makers in a clear way is the ultimate goal of e CGIAR Foresight team.

No single source of information focuses regularly and systematically on the future of food and agriculture, and challenges facing developing countries. Our work aims to fill that gap with a focus on agricultural income and employment.

group systematically collects information about past, on-going and planned foresight activities across CGIAR centers and their partners, spanning the global agricultural research for development arena

We present a comprehensive overview and synthesis of the results of relevant foresight research, which through the tagging with metadata allows for customized investigations in greater detail. The crosscutting nature of this work allows for a more comprehensive picture and assessments of possible complementarities/trade-offs.

Potential users of this report and associated activities include CGIAR science leaders and scientists as well as the broader research community, national and international development partners, national governments and research organizations, funders, and the private sector.

The approach developed by the CGIAR foresight group is used to make foresight study results accessible across organizations and domains in order to aid policy and decision makers for strategic planning. The approach allows visualization of both the available information across multiple entry points as well as the identification of critical knowledge gaps.

\section{Highlights}

- Investments that lower costs of getting farm produce to market lead to the largest gains in per capita incomes in Latin America and sub-Saharan Africa.

- Rural households in South Asia and sub-Saharan Africa will follow trends observed in East Asia and Latin America towards increasing diversification of livelihoods, especially towards more nonfarm work.

- Emerging evidence suggests that trends towards increasing numbers of medium size farms in Africa will continue in the future, with potentially major implications (both positive and negative) for agricultural technology adoption and labor demand.

- Investments in agricultural research to close the yield gap in developing countries are projected to generate future benefits of about USD 7 trillion in 2050, mostly in Asia.

- Digitalization of agri-food systems will play an increasingly important role in finance and extension services, markets and value chains, safety nets and risk mitigation strategies, with potentially profound impact on agricultural income and employment. 


\section{Table of Contents}

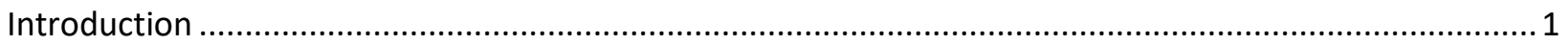

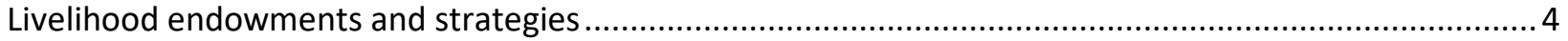

Production technology, finance and extension services ….............................................................. 8

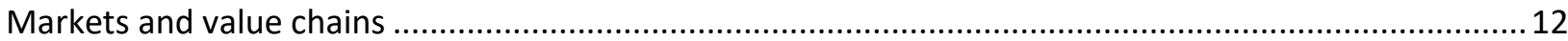

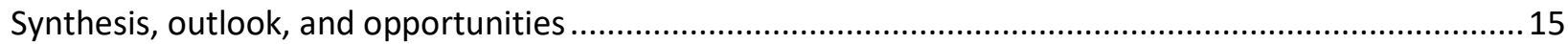

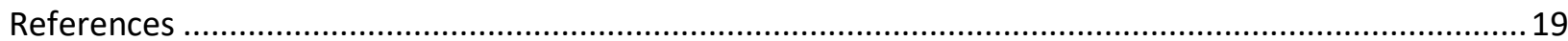




\section{Acknowledgements}

This paper was prepared with support from the CGIAR Research Program (CRP) on Policy, Institutions, and Markets (PIM). Additional support was provided by the CRP on Wheat, and CRP on Maize.

\section{Authorship}

Gideon Kruseman coordinated the review of foresight related work regarding agricultural employment and income and therefore acts as first author. The co-authors contributed equally to the review in its various stages of development. The order of the co-authors is alphabetical. 


\section{Introduction}

Food, land, and water systems are facing unprecedented change. The world's population is projected to grow to approximately 10 billion people by 2050, while aging and declining in some regions. Global average incomes are expected to keep increasing at a slow but steady pace. With increasing incomes and the ability of consumers to purchase more and better food in combination with population growth, food demand is projected to grow substantially over the next three decades. Meanwhile, demographic changes and economic development also drive urbanization, migration, and structural transformation of rural communities. Currently, humanity is approaching or exceeding planetary boundaries in some areas, with over-use of limited productive natural resources such as water and phosphate, net emissions of greenhouse gases, and decreases in biodiversity. This all is aggravated by continuous climate change.

Much is published about food and agriculture, but no single source focuses regularly and systematically on the future of agriculture and food systems, particularly on the challenges and opportunities faced by developing countries. This working paper is part of an effort by the CGIAR foresight team to help fill that gap. The effort recognizes that there is much to learn from past experience, and there are clearly many urgent and immediate challenges, but given the pace and complexity of change we are currently experiencing, there is also an increasing need to look carefully into the future of food, land, and water systems to inform decision making today.

The work can be distinguished from other efforts related to food and agriculture (e.g. ISDC's 2018 volume edited by Serraj and Pingali, FAO's annual State of Food and Agriculture report (FAO 2020; 2021; 2019), IFAD's periodic Rural Development Report (IFAD 2016; 2019; 2021), OECDFAO's annual Agricultural Outlook report (OECD and FAO 2020; 2021), the World Bank's World Development Report (World Bank 2008; 2010; 2021), and others) in terms of time horizon, geographic or thematic focus. The work adds to other foresight analyses, e.g. studies by IPCC (2019), AgMIP (Elliott et al. 2015; Robinson et al. 2014; Antle et al. 2016; Challinor et al. 2018; Rosenzweig et al. 2013, 2018), TWI2050, WRI (Dumas et al. 2019; Carter et al. 2021), GCA (Loboguerrero et al. 2018), the EATLancet Commission (Willett et al. 2019), and note also the recent perspectives on One CGIAR in Food Policy (Barrett 2020).

We note that much existing work on the future of agriculture and food systems offers a global perspective, often focusing on diets and health, or land conversion and greenhouse gas emissions. Our intent is to focus on the future of agriculture and food systems from a developing country perspective, i.e. within a global context but with greater focus on livelihoods, food security and nutrition, and impacts of climate and other environmental change on vulnerable populations in developing regions.

Our goal is to provide strategic foresight rather than a more tactical perspective, with a broader and longer-term horizon to support a shared information base for decision-making rather than recommending specific priorities. This is clearly aligned with the special need and opportunity provided by the One CGIAR reform process (CGIAR System Organization 2021; Barrett, 2020). In this process there is a focus on projecting potential benefits of investments in the CGIAR research portfolio in the five impact areas of CGIAR, namely, income and employment, improved health and nutrition, gender equity and social inclusion, climate change adaptation and mitigation and environmental sustainability and safeguarding essential biodiversity.

Moreover, we recognize the special urgent and immediate concerns arising from the current global pandemic that has direct links to the food system, with implications for food systems not only this year but into the future. 
To that effect we are developing a series of discussion papers focusing on particular aspects of complex dynamic agri-food systems in transition. The consolidated effort draws on the unique expertise and experience of all CGIAR Centers and CGIAR Research Programs, including the CGIAR foresight community of practice, as well as partner (and other) organizations around the world.

The current manuscript focusses on agricultural income and employment. In this discussion paper we explore how capital endowments, agricultural technology and finance services, livelihood strategies, and markets and value chains are likely to interact in the future. By endowments we mean land, physical, financial, and human capital. We particularly examine how primary drivers exogenous to agri-food systems are expected to affect income and employment opportunities of present and future CGIAR target beneficiaries.

We take a systems approach - focusing on drivers, pressures, states, impacts and responses - to structure the narrative, placing the systems approach in a foresight context to better illustrate what we already know about the projected impacts of alternative investments in different agricultural-oriented development domains in the future. This approach allows us to highlight the alternative development pathways available for the resource poor in low- and middle-income countries. It also allows us to explicitly consider social inclusion and inequality issues under such contexts.

Rural transformation is key component of how climate change, overall economic development and population growth (as well as aging and decline in some areas) will increasingly drive urbanization, migration, and rural transformation in developing countries, offering opportunities for some and increasing vulnerability for many.

CGIAR's international agricultural research generates substantial benefits for its target populations (e.g., over 4 billion dollars annually for wheat alone (Lantican et al. 2016) that vastly outweigh total R\&D investment across the system, in line with past findings on the benefits of agricultural R\&D for small holders (Evenson and Gollin 2003; Renkow and Byerlee 2010; Raitzer and Kelley 2008),foresight studies on projected future benefits (Rosegrant et al. 2017; Prager and Kruseman 2021) show how these trends might continue and offer insight as to different geographical and thematic priorities.

Unpacking the drivers and pressures affecting the relationship of agri-food systems with income and employment and linking this understanding to investment decisions is a complex task. Figure 1 summarizes the overall conceptual framework on how these major changes shape decision making for the target beneficiaries of the CGIAR. 


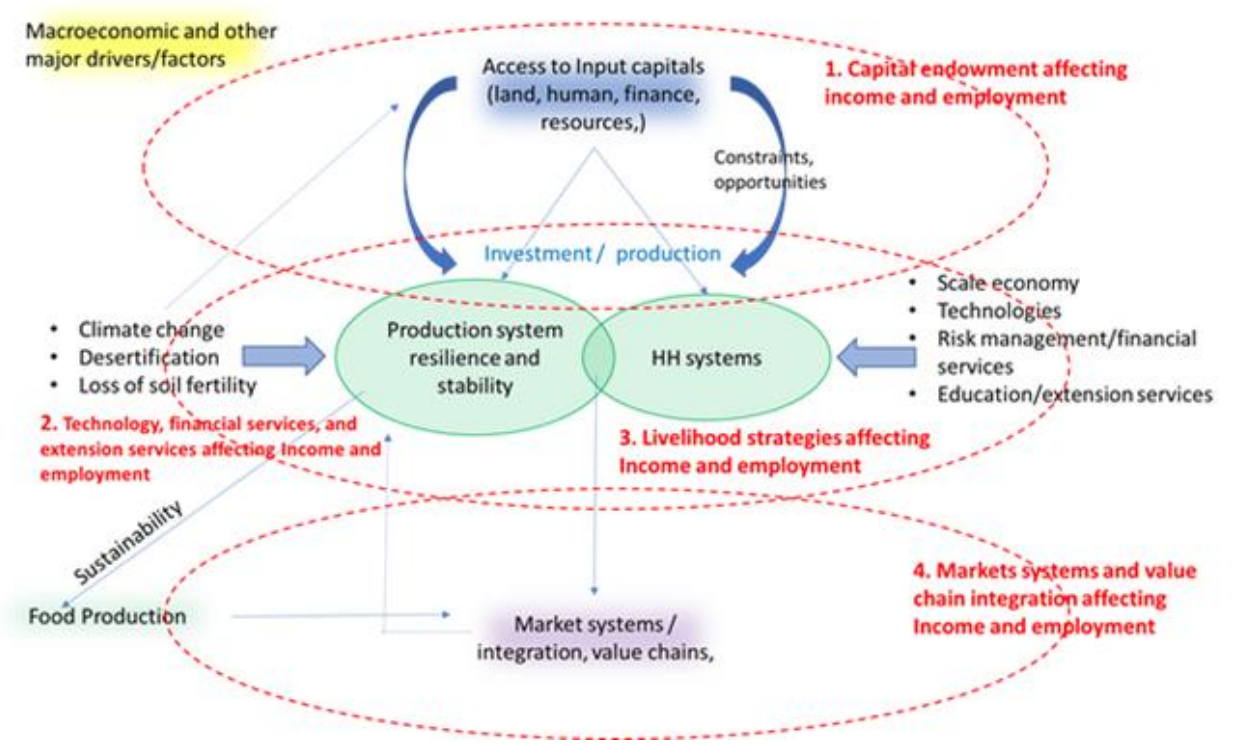

Figure 1: Drivers and factors affecting agricultural income and employment.

Figure 1 illustrates four conceptual levels (in red) having direct and indirect relationship on agricultural income and employment. These levels were tackled in the previous sections to better understand the available information in terms of their respective importance from a foresight perspective. They will also be considered in this section to better highlight the main insights, conclusions and gaps for future research within each of these domains in relation to income and employment. An important element is that population growth and levels of overall economic development do shape the options and agricultural production possibilities that can be seized by smallholders in low and middle-income countries. These drivers are further compounded by the effects of climate change. Most of these drivers will keep emerging, as contextual elements, when analyzing/reflecting on functional relationships between the four highlighted conceptual levels on one hand, and agricultural income and employment on the other hand.

In the following sections we will address these key issues. In section 2, we discuss livelihood endowments and strategies. In section 3, we discuss production technology, finance, and extension services and how it relates to stimulating income and employment. In section 4, we discuss markets and value chains. In the process we determine what the key drivers, pressures and response mechanisms are that are of importance for priority setting of investment decisions related to agricultural research for development. 


\section{Livelihood endowments and strategies}

A livelihood refers to the totality of people's lives and includes capabilities, assets, and activities that are required to sustain a standard of living (Scoones 1998). People live in specific vulnerability contexts and they draw upon their assets to generate a livelihood, these assets interact with agricultural technologies, policies and institutions to shape livelihood strategies that in tun effect livelihood outcomes, such as income (cash and in-kind income), as well as the social institutions, gender relations, and property rights. Five broad types of assets include natural capital, financial capital, physical capital, social capital, and human capital. Here, we focus on the livelihood strategies of farm households that are determined and shaped by their underlying livelihood resources or endowments, and how these strategies ultimately affect outcomes such as income and employment (Ellis 1998). Foresight analysis can examine the effect of temporal changes in endowments on livelihoods strategies and outcomes. However, the focus of foresight studies has been on the changes in human and natural capital which in parts have direct implications on the other capitals. Foresight studies typically use quantitative methods like mathematical programing models (Berger et al. 2017; Kruseman, Bairagi, et al. 2020) and this makes it hard to examine adequately social capital (such as involvement in social networks, which are often qualitative data) and given the limited access to financial assets for many farm household in developing countries, social and financial capital are less studied in foresight analyses than human and natural capital.

Human capital includes, for example, education, skills, and labor. Population growth leads to relative scarcity of land resources per person in the absence of movement out of agriculture. Economic development has long been recognized as partly associated with structural change, occurring when members of the workforce, including young people and women, leave agriculture for more remunerative jobs in other sectors (Kilby and Johnston 1975; Chenery, Syrquin, and Elkington 1975; Mueller and Thurlow 2019) . Labor migration, whether it is rural-rural, rural-urban or international out-migration, changes the relative labor supply in different areas with different dominant economic sectors. While urbanization is expected to influence food consumption patterns, farm size is however supposed to influence food supply (Fan et al. 2013) Furthermore, specific implications of changing gender roles influence the human capital dynamics on farms. Female participation in paid employment is expected to change over time due to improved education participation with two effects: better education leads to higher female participation, but higher education also leads to delayed entry of women in the workforce(Fouré, BénassyQuéré, and Fontagné 2013) ). In the case of sustainable intensification of agricultural systems, increasing labor demands may burden women disproportionately more than men in the future, especially if hired labor is not readily available(Gatto et al. 2020) .

Natural capital, in the farming context, builds on available land and water resources. It should however be noted that this is not only about the quantity of available land but also the quality of land. Pressures such as land degradation and desertification affect the quality of land endowments in many parts of the world. This is exacerbated by water shortages. (These points will be discussed further in section 3.3.) As we try and plan for changing human capital endowments, foresight analysis plays a critical role in helping us understand the future dynamics of land endowments (natural capital) in these contexts. In highincome countries the process of reduction in the number of farms and hence the increase in average farm size has been ongoing since the mid-20th century (Kislev and Peterson 1982; MacDonald et al. 2013; Hermans et al. 2017). There is a positive correlation between GDP and average farm size (Adamopoulos and Restuccia 2014). Rural transformation processes in Latin America lead to parallel development pathways for small, medium and large-scale enterprises (Kruseman et al. 2020) The key question is what this will mean for farm size development in the future, particularly in low income countries in sub-Saharan Africa and Asia under simultaneous population and GDP growth. Intensifying land scarcity potentially 
increases processes such as rural-rural migration to areas where land is still available, and potentially puts greater pressure on non-farm sectors to absorb rural labor in densely populated areas (Jayne, Chamberlin, and Headey 2014). Land aggregation and capitalization is in part due to foreign direct investment driven by land fees that are either small or lacking (Zerfu Gurara and Birhanu 2012; Santpoort 2020) . Rosegrant et al. (2017) project that the per capita availability of land will decline in many developing regions in the future. For example, in Asia, this ratio was 0.033 land per person in 2010, and it is expected to decline to around 0.026 in 2050, a $22 \%$ decline. The largest percentage decline is projected in south Asia (31\%). Land fragmentation and small farm size is a common phenomenon in many developing countries. The average size of farms in Bangladesh, for example, is about 0.68 ha. In Egypt, $50 \%$ of farmers are cultivating less than one ha of land; while the average farm size in China, Indonesia, and Vietnam is respectively about 0.4 ha, 0.8 ha, and 0.7 ha (Larson et al. 2016). Generally, farmers smaller than one ha of landholdings can hardly fulfil their subsistence requirements through agriculture (Niroula and Thapa 2005).

Resulting Livelihood strategies. The livelihoods endowment and developments are used by households to develop their livelihood strategies. These go beyond the farming components of the income portfolio and do include off farm activities such as wage employment or migration. A gap in current foresight work appears when looking at the interactions between farming choices and off farm income opportunities. Off-farm employment as an alternative for parts of farming household's income portfolio has been identified as one avenue to reduce land pressure. For agricultural incomes the options can be summarized as "hanging-in" (maintaining current position under adverse conditions), "stepping-up" (expanding current activities through investments) and "stepping-out" (using current activities to accumulate assets to provide the base for new endeavors) (Dorward et al. 2009) .

The complex linkages been agricultural growth and poverty reduction require precision on the treatment of what is meant by poverty and, likewise, the mechanisms of how sectoral dynamics can serve to potentially contribution to poverty reduction. Poverty can be defined broadly or narrowly. When considered broadly, poverty is widely recognized as a multidimensional phenomenon that accounts for multiple deprivations including, for example, adequate access to services such as education and healthcare that are often publicly provided. Prager and Kruseman (2021) using the IMPACT model results and semi-elasticities that vary with the poverty line and gini-coefficients, estimate high returns to investment in international agricultural research for development in terms of poverty reduction. These calculations support the idea that agriculture can serve as a mechanism to reduce gender disparity in agriculture development.

Implications of natural capital dynamics. The recurrent choices a household is making in this context are determined by their initial endowment and its anticipated evolution, among others. In the small farm context, these choices can already be limited (factually or perceived) as the financial returns have to cater for various household cash needs. Within the household these choices are further refined within the context of cultural norms, practices and institutional arrangements which may inhibit parts of the population from making specific choices. Their natural capital might be constrained as they may for example not be allowed to own land and thus not invest in longer-term agricultural practices - which frequently happen to be the more sustainable/environmental-friendly ones (such as agroforestry or conservation agriculture). Productivity-enhancing technologies of dryland crops (cereals and legumes) have been shown to increase household incomes and also provide incentives for conserving soil moisture and fertility (Nedumaran et al. 2014). Bio-economic modeling in Malawi assessed how subsidizing the price of mineral fertilizer would reduce legume area planted, but still increase farm income as fertilizer use and therefore maize production increase (Komarek et al. 2017). Other studies using bio- 
economic models show that subsidizing cultivation of rice on lowlands in Sierra Leone would increase farm profit but not caloric intake, suggesting a caloric-income tradeoff (Roza et al. 2017) .

Implications of human capital dynamics. These factors already often lead to coping mechanisms like migration to seek more lucrative or generally viable livelihood options elsewhere. If this migration is partial, it puts further pressure on the endowment of the household members who are left behind as labor and capital resources are needed or used for other ventures. Extension or other education programs can play a role here by lifting the human capital stock and broadening the choice windows available to these households and enabling them to generate higher incomes. Therefore, different development pathways identified with foresight analysis are crucial for identifying the changing livelihood strategies within rural transformation processes. Migration and structural shifts that move large parts of the rural population away from agricultural production can have direct and potentially serious consequences for food production and availability as well as the natural environment in which food is produced (see also sections 3.2 and 3.3). Livelihood strategies must balance among tradeoffs between having fewer people for manual labor vs receiving remittances, among others. Additionally, resource conservation or regeneration efforts most often are labor demanding and migration further limits households' ability to implement these. However, by and large, migration does not negatively affect agricultural production, as households shift on one of several margins to reduce the lost labor impact (De Brauw 2019) .

Each of the types of capital can interact with agricultural technologies to influence livelihood outcomes. For example, Population growth, which is projected to continue for SSA, is one of the main determinants of income opportunities from farming as the per-person income from fixed land sizes will fall under current practices. This has been analyzed for Malawi highlighting that, by 2050, per-person crop production and income may fall by $21 \%$ compared to 2013 values if current farming practices prevail. However, assuming yield-enhancing technology adoption, per person crop production and income could increase in 2050 by $8 \%$ compared to 2013 values (Komarek and Msangi 2019).

Implications of the context. A common livelihood improvement strategy centers on increasing agricultural productivity; however, the evidence on the role of agricultural productivity in assisting households move above the poverty line is mixed. For example, the prospects of generating incomes above the poverty line for small farms from on-farm production are limited (e.g. Harris and Orr 2014; Harris 2019; Gassner et al. 2019). Therefore, simply raising the productivity of smallholder farmers will not likely be sufficient to solve the rural income or poverty issue in the future. Stimulating the rural non-farm economy and creating jobs are complementary policies for smallholders to improve their livelihoods (Wiggins et al. 2010). Agricultural incomes are not generated in isolation and are always embedded into the larger economy. Households therefore make choices between their various income generation activities (such as crops, livestock, nonfarm and off-farm) where agricultural (and other) choices are embedded into the resulting livelihood portfolios.

One of the key contextual factors in livelihood analysis is the vulnerability context households must live with as it can alter the availability of assets and change the mindset of people, and ultimately livelihoods outcomes such as income or food supply. The inherent risk in agricultural production further constrains strategy. Risk management has always played a major role in farm household decision making in all geographies and across time. Risk can be linked to abiotic stress such as climate change (Tesfaye et al, 2018) that leads to water and heat stress (Deryng et al. 2014; Cairns et al. 2013; Chung et al. 2014; Gbegbelegbe et al. 2014; Tesfaye et al. 2018) or biotic stresses, such as pests and diseases (Duku et al 2016; Mottaleb et al. 2019; Mottaleb et al. 2018; Yigezu et al. 2010), market risk (Yigezu and Sanders 2012), institutional risk, individual risk (like health or safety), and financial risk. Most studies on risk in the 
agricultural systems literature examine only production risk or production and market risk. Although these are major risks facing farmers, farmers often face multiple risks at the same time and without examining all the risks farmers face simultaneously, developing holistic options to manage risk will be hampered (Komarek et al. 2020). 


\section{Production technology, finance and extension services}

With sustained or rising demand for agricultural commodities in developing countries (Sharma 2014; AlaeCarew et al. 2019; Zhou et al. 2016; Desiere et al. 2018), increased production efficiency should lead to higher producer incomes (Michler 2020; Zhang et al_2018). A standard assumption arising from this observation is that smallholder producers who traditionally have grown the commodities that are now seeing higher demand (e.g., cereals, vegetables, fish and livestock products) will gain economically as they ramp up their production to meet this demand (Enahoro et al. 2018; Baltenweck et a;. 2020). This is often facilitated by more reliance on improved inputs (Michler, 2020) and mechanization. The adoption of new crop technologies (e.g.s water-stress-tolerant or heat-tolerant rice and cereal varieties) and/or management practices soils (e.g., such as Zero tillage, crop-livestock integration, forage seeds systems, livestock breeding programs, etc.) will be key to this outcome (see Dawe et al_.2014; Yamano et al. 2016; Larson et al. 2016; George 2014; Arouna et al 2017). Investments in national and international agricultural research -potentially increase the availability of such technologies in developing countries, and could lead to increases in both productivity and producer incomes among other benefits. A 2006 study showed that an aggregate investment of 7120 million (in 1990 US dollars) in the CGIAR resulted in research benefitcost ratios ranging from 1.9 to 17.3 , depending on scenario, with the true value of benefits likely in excess of even the upper bounds of these results (Raitzer and Kelley 2008). At least one study has suggested that the positive benefits to international agricultural (CGIAR) research may have been in the form of production increases rather than productivity gains (Evenson and Gollin 2003). However, other studies cite large scale crop genetic improvements (e.g., Renkow and Byerlee 2010; Maredia and Raitzer 2012); as well as (geographically) localized positive impacts on productivity growth and income generation (Alene et al. 2009; Alene and Coulibaly 2009). Broader overview of global agricultural research investments in Asia and SSA with precise estimates that can inform research prioritization can be found in (Raitzer and Maredia 2012; Adetutu and Ajayi 2020). In many countries that could potentially benefit from research to increase agricultural productivity, large-scale interventions are however needed that will enable smallholders to overcome other struggles, such failures in agricultural input and output markets, from low availability of and access to appropriate technology, to inadequate finance support, and limited market options (Dillon and Barrett 2017). On a global level, projections to 2050 showed that investments that lower costs of getting farm produce to market likely lead to the largest gains in per capita incomes in Latin America and sub-Saharan Africa (Rosegrant et al. 2017).

Work by Alene and Coulibaly (2009) showed that agricultural research is reducing the number of poor people in the low and middle-income countries by 2.3 million annually; while forward-looking assessments have estimated the potential income gain from additional investments in international and national agricultural research investments, to the national economies of developing countries at USD 6.53 trillion by 2050, and up to USD 6.94 trillion if global effects are accounted for (Rosegrant et al. 2017). An ex-ante study by Balié et al. (2021) regarding prioritization of agricultural research in the Philippines estimated that the optimal allocation of funding across crops generates aggregate economic benefits of more than USD 950 million, lifting 880 thousand people from poverty. In addition to this, optimal allocation generates additional income of USD 79 million per yar compared to standard rule-ofthumb (allocation proportional to value of production). Research by Mottaleb et al. (2017) found that a successful drought-tolerant rice variety could provide yield gains of between $1.71 \%$ and $8.96 \%$ in South Asia under different climate conditions, with economic benefits that more than outweigh the initial investments. In the case of virus-resistant peanut varieties in Uganda, an ex-ante analysis by Moyo et al. 
(2007) showed that huge research benefits can be generated from the adoption of these varieties. In particular, the estimated benefits of adopting Rosette-resistant varieties would reach USD 35.6 to 62.0 million (open economy assumption) and USD 34.0 to 58.3 million (close economy) over fifteen years. Similar ex ante analysis in Nigeria showed that higher cassava yield would increase average household income by $0.2 \%$, leading to aggregate benefits of USD 219 million per year, poverty reduction by 0.2 percentage points, and lifting an estimated 385 thousand people out of poverty (Minot and Huang 2019). Similar work showed that targeted investments in the livestock sector in Sub-Saharan Africa and South Asia could improve producer incomes in these regions and food security globally (Enahoro et al. 2019). Other studies have shown that vegetables, fruit and aquaculture (Raitzer and Maredia 2012). The potential increases in income are substantial, with another study finding that sustainable intensification of rice-based systems with potato may generate up to USD 800 million over a 20-year period in West Bengal in India and Bangladesh (Gatto et al. 2020). Other effects of R\&D investments would also relate to nutrition and hunger. Mason-D'Croz et al. (2019) estimated that increased agricultural R\&D can reduce the prevalence of hunger by 55 million people in Africa by 2050. These studies however do not assess farm-level benefits.

At the farm level, investments to enhance total factor productivity through technology adoption have however been found to be less likely associated with employment or income creation in low-income countries compared to what will occur in lower-middle-income or upper-middle-income countries (Fuglie et al. 2019; Ugur and Mitra 2017). For many small farms, gains from adopting improved technologies may not be enough to assist households out of poverty, an observation found to hold for producers of both crops (e.g. Harris 2019; Harris and Orr 2014) and livestock (Minten et al. 2020). One implication is the need for smallholders to establish collective farming and are supported by public funds, as shown by oil palm smallholders in Peru (Bennett et al. 2019). Meanwhile, in Indonesia, formal land titles and access to additional land are important factors for increased livelihoods of oil palm smallholders (Krishna et al. 2017; Kubitza et al. 2018). Some forward-looking studies estimate that the gains to closing yield gaps among the poorest farmers will likely accrue mainly to nutrition, as opposed to incomes (Govaerts 2019; Tanumihardjo et al. 2020; Enahoro et al. 2018,; Gassner et al. 2019). The future relationships between agri-food system and gender, poverty, and nutrition (GPN) are important, but missing particularly as it relates to technology adoption. By using a system perspective to synthesize existing agriculture and food foresight studies, Lentz (2021) has raised valid concerns about the risk of deepening inequalities and nutritional and gender disparities to a greater extent without explicitly capturing GPN outcomes into foresight work. Lentz (2021) pointed out that ignoring gendered barriers to technology adoption could lead to promoting technologies that aggravate gender inequality. In this regard, Lentz (2021) advocates for providing future foresight work that captures interactions, trade-offs, and synergies across interventions and among outcomes.

Yield gaps and broader low factor productivity do have direct implications on farm incomes and weaken the capacity of farmers to accumulate savings. The translation of productivity gains to higher incomes and related benefits has been hindered by the lack of many enabling conditions. Evidence suggests that technology intensification (technology transfer chains, availability and access, extension services patterns), access to diversified and adapted financial services (including financial services that can help deal with climate events and their impact on income and investment), access to better logistic and marketing options (including organizational such as cooperatives, as well as logistical and infrastructure related factors) could contribute to enhancing factor productivity in the future and to overcoming some 
of the market failures faced by smallholder farmers (Collier et al. 2014; Larson et al. 2016; Dzanku et al. 2015; Van Ittersum et al. 2016). There is also evidence that infrastructure investments can lead smallholder producers to commercial decision-making that aids the conservation of environmental resources (Acheampong et al., 2018). The appropriate combination of these factors and needed solutions for enhancing productivity and promoting sustainable development of smallholder farming have also been found to be highly contextual, being heavily influenced by farm typologies, socio-ecological settings and economic structure.

Agricultural investments do also actively contribute to labor markets in the rural areas of developing countries. Distributional effects of employment growth, which are associated with the economic structure and performance of relevant economic institutions, however, vary both between and within countries (Rao 2012). Relying on published parameters of employment elasticities to GDP growth, Frija et al. (2020) converted measures of agricultural income growth due to different (technology and nontechnology oriented) R\&D investments, to estimates of employment generation for a set of 14 African countries. The study, which utilized a quantitative foresight framework running simulations to 2050, projected that agricultural research investments will have a higher impact on employment in Africa compared to additional investments in infrastructure (such as irrigation, roads, electrification, land development) that facilitate and enhance market integration. This result holds despite related studies (Rosegrant et al. 2017) indicating that market-enhancing investments will generate the highest economic gains in sub-Saharan Africa (and Latin America) than elsewhere. According to Frija et al. (2020), the different agricultural investments scenarios do increase female employment more than male employment in 8 out of the 14 countries studied, a result closely reflecting the structure of their agricultural sectors. The results suggest important gendered benefits could be gained in the future from making agricultural research investments in key countries relevant to global development.

Investments complementary to agricultural yield improvement are particularly relevant in low resource settings. This is the case for financial services that allow the adoption of costly technologies (Yigezu et al. ${ }_{2}$ 2018), increased stability of farm incomes, and increased investments, including those related to the management of critical natural resources (Balana et al. 2019). Access of farmers to credit and other financial services and their impacts on farmers' incomes are often-studied topics in agricultural development. However, the issue of financial services has become even more relevant in light of emerging challenges from climate change, and income risks from extreme climate events such as drought and flooding, leading to the need for more diversified financial services to be developed, tested and validated (Oostendorp et al. 2019). Financial solutions that stimulate or sustain self-employment seem to be extremely important for the most marginalized rural populations with limited access to productive assets, or that heavily rely on assets that are highly vulnerable to systemic risks from climate events or agroecology (e.g., Taye et al. 2019). The need for financial services under these conditions will include micro-credit and other forms of similar financial services for underserved populations and/or events, in addition to social security programs, and schemes that can lead to coverage for men, women and youth in seasonal agricultural sectors.

-Recent studies have worked to identify the best designs for safety nets to complement programs on enhancing agricultural growth and rural transformation (See CRP PIM work on-social protection for agriculture and resilience, under flagship 4: https://pim.cgiar.org/research/f4/). For example, recent work has explored how index-based insurance could enhance climate resilience while addressing gender and social inequalities for rural farmers in India and Bangladesh (Amarnath et al. 2019). Studies such as these 
provide a better understanding of how alternative instruments for social assistance delivery (e.g., insurance, cash, vouchers, food) perform in harmony or against one another, how to target beneficiaries, and how large transfers ought to be. Attention is also turning to the role that demand-side investments, mainly by private agents, will play an important role in providing incentives for smallholders to modernize their production (de Janvry and Sadoulet 2020).

Appropriate policy research and increased engagement between research, policy and industry are also important to support the upgrading of agricultural and livestock systems in developing countries to meet employment generation and related aspirations (Enahoro et al., 2019b). An example of this are the research-based livestock master plans (LMP) that help guide the investment planning of countries' livestock sectors after the major political decisions on budget allocation have been made. LMPs build on evidence in translating livestock production intensification and value chain development into employment, nutrition and other gains for developing countries using a combination of foresight modeling and stakeholder consultation. This evidence has translated into important development outcomes. For instance, based on the Ethiopian LMP, the government has invested public funds to improve primary production through improved animal genetics and vaccination programs to lower ruminant morbidity and mortality (Shapiro et al., 2015). It is also establishing four agro-industrial parks to support value-added processing (with the support of the EU and FAO+. Furthermore, private investment of more than $\$ 250$ million in the processing sector has taken place, including a USD 145 million investment in two abattoirs by two meat export companies with large feedlots. The Government of Ethiopia and the World Bank have also just launched a USD 170 million livestock sector program based on the LMP. Growing demand from developing countries for LMP-type support provide avenues in the future to further transform research outcomes into employment generation and related objectives of national governments in countries in which the CGIAR is active. 


\section{Markets and value chains}

Future agricultural demand needs to be characterized (customer segments; product profiles), strengthened and involve safer and more environmentally friendly foods from crops, livestock and fish. Marwaha (2010) used a foresight study to show that supporting rural employment in the potato sector in India would require a strong and sustained demand for potato products in domestic and foreign markets. With rising urbanization across the developing world, retail food markets are changing. More specifically, supermarkets are projected to grow in numbers and food safety issues are also projected to become more important (Reardon \& Berdegué, 2008). For some developing countries, ensuring food safety for the masses would involve a flexible retail modernization approach that does not focus on supermarkets alone (Wertheim-Heck, Vellema, \& Spaargaren, 2015). Early work showed that informal milk markets created more employment per unit of product than did formal markets in Kenya, Bangladesh, and Ghana, and has been the bases for the longstanding involvement of CGIAR researchers in dairy sector reforms in Kenya (Jabbar et al., 2020).

Marketing costs along agricultural value chains need to be reduced to support rural incomes and employment. Adequate measures are required to minimize post-harvest losses, process agricultural produce for longer shelf-life and mitigate the negative effects of climate change (Prager et al. 2021). Although processed food demand is increasing In addition, transport costs should be reduced to facilitate movement of agricultural produce. In the poultry value chain in Mozambique (Karnani \& McKague, 2014), research was used to identify solutions where required. In addition, post-harvest losses for some crops are related to market access and can be reduced through both breeding and post-harvest measures (Minten et al., 2020; Ncube and Maphosa, 2020). Here, research should be used to identify the most cost-effective mix of approaches required to minimize market costs and post-harvest losses for staple food crops. Foresight analysis of livestock value chains in West Africa showed low capacities of producers to meet higher and changing demand, with key interventions for impact found still to be upstream, including improved herd disease and inventory management (Enahoro et al., 2021).

Some ex-ante studies have shown that building roads in addition to promoting agricultural productivity generate greater benefits to smallholder farmers in some developing countries (Arndt, Jensen, Robinson, \& Tarp, 2000; Gollin \& Rogerson, 2010) as some rural areas are still cut off from major roads and markets (Gbegbelegbe et al., 2017). Apart from better road networks, digital resources and big data could be used to reduce communication costs and ensure that smallholder farmer can easily access market information for both inputs and outputs (Wossen et al., 2017; de Ruyter de Wildt et al., 2019, CTA 2019, AGRF 2019). Digitalization of agriculture as part of livelihood strategies of the resource-poor depends critically on markets and service provision, enabling policies and institutional arrangements more than on the technology itself, e.g., mobile money based social safety nets depend critically on access to mobile phones (Peterman et al., 2019), as is the case with picture-based insurance (Kramer et al., 2017). In several parts of the world, COVID-19 pandemics have shifted several value chain activities, ranging from the use of information and communication technologies to product delivery. Pandemics have increased online transactions involving both direct transactions between the producers and consumers and transactions in e-commerce, resulting in the rise of direct product delivery. With several restrictions enforced to enter places with potential crows such as supermarkets, this trend is reducing the length of the agricultural value chains between producers and consumers (Reardon et al. 2021). 
Good governance across agricultural value chains would require strong involvement from national policymakers who should strengthen market institutions where required (Pinstrup-Andersen \& Pandya-Lorch, 1998). At the same time, the role of large-scale agricultural producers cannot be neglected (cf Pacheco et al. 2020). For one, agricultural produce from farm and processors should meet minimum acceptable standards to facilitate uptake by consumers; in addition, certification and tax systems targeting climate change mitigation should be considered for value chains involving both crops, livestock and fish (Weindl et al., 2015). Cost-effective price stabilization mechanisms should also be implemented for domestic and export markets (Dawe and Timmer 2012; Poulton et al. 2006; Yadav et al. 2016). Better and stronger linkages would also be required between researchers, extension personnel and policy planners along value chains (Singh, 2010). Recent research in India and Kenya have highlighted the dominance of the informal sector in agricultural value chains (Mishra and Dey 2018; Kiambi et al. 2020); in addition, it appears that value chains which are dominated by the informal sector were not driven by retailers as seen in formalized value chains. In other cases, informal sector actors also participate in the formalized value chains through linkages with large formal sector actors, for example in the palm oil sector (Pacheco et al. 2020). Such knowledge has implications on the type of regulations and governance policies required to enhance inclusive value chain development. In this regard, research can be used to assess and identify adequate governance mechanisms for the complex agricultural value chains found in the developing world (Devaux et al. 2018).

The participation in Global Value Chain (GVC) can significantly contribute to productivity improvement, economic growth, job creation and poverty reduction (Rigo 2021; World Bank 2020). An increase of participation in GVC could also reduce the competitiveness gap between small and large firms (Boffa et al. 2021). However, appropriate policies and reforms are needed to curb barriers to market access for small and medium size producers (Lee et al. 2012; Montalbano et al. 2018). Even though the role of developing countries in GVC is increasing, the impact of resulting knowledge transfer on their innovation performance requires more investigation (De Marchi et al. 2018), as well as the relationship between GVC participation, technological progress, and environmental pollution (Wang et al. 2021). In addition, agrifood value chains need to be well-integrated with the broader domestic economy in terms of growth. Better integration of the farming sector with the other economic sectors would support rural transformation and enhance rural employment and incomes (Kruseman et al., 2020b). Where rural-urban transformation is currently happening, close monitoring and tailored policies would be required to ensure net societal gains from the process. For example, Li et al (2019) found that creating a new town, enhancing multi-skilled education and better integration of the farming sector with the industrial and services sectors would be important to support future rural transformation in Miyun district, China (Li et al. 2019). However, future urbanization and education when unaccompanied with agricultural innovations, including mechanization, could have negative effects on future food security and the environment (Kuiper et al. 2019). Indeed, rising urbanization and education could reduce the amount of unskilled labor used in agriculture; hence, such labor would become pricier and could lead to higher food prices and worsened food security. In addition, the fewer labor force involved in agriculture might turn to agricultural extensification and this might worsen the negative impact of agriculture on the environment when accompanied by expansion of agricultural land. In such case, sustainable agricultural intensification driven by agricultural innovations including mechanization could reduce the negative impact of rising education and urbanization. Many other foresight studies have identified policies on finance and education which could help smallholder farmers in the developing world adapt to climate change (Habtemariam et al. 2016; T. Wossen and Berger 2015; Yalew et al. 2018). These measures consist of enhancing farmers' access to 
credit while strengthening their income-earning capacity (Dantwala 1989; Ebi et al. 2011; Habtemariam et al. 2016). They also involve increasing access to extension services (Habtemariam et al. 2016). Additional policies should aim to enhance skills in rural communities to make it easier for rural people to adapt to future climate change by helping them transfer out of subsistence agriculture (Wossen and Berger, 2015; Yalew et al. 2018).

Shocks including conflicts, weather extremes, emerging plant diseases, and human diseases like covid-19 can have a big impact on the likelihood and intensity of adverse events affecting agricultural value chains. Weather extremes are projected to increase in frequency or intensity in various parts of the develop world. For example, droughts are projected to become more intense in central America and southern Africa (Seneviratne et al., 2012). Small islands are projected to experience rising sea levels. Such events will have adverse effects on agricultural production and would jeopardize the existence of entire value chains. Already, most countries in sub-Saharan Africa have decided to enhance domestic food production and reduce food import dependency given the shocks that have recently affected world food prices and led to sharp increases in food import bills across the region (African Union 2014). Foresight research should be used to identify adequate policies to enhance food security and reduce poverty amidst shocks. 


\section{Synthesis, outlook, and opportunities}

Unpacking the drivers and pressures affecting the relationship of agri-food systems with income and employment and linking this understanding to investment decisions is a complex task. Figure 1 (see introduction section) summarizes the overall conceptual framework on how these major changes shape decision making for the target beneficiaries of the CGIAR.

It is not yet clear which interacting economic, institutional and social factors pose the most limiting constraints to translating increased agricultural productivity to higher incomes, and as such what combinations of enabling factors will be most effective. This dilemma is made more complex by the highly contextual nature of solutions imposed by fundamental differences in farm typologies and socio-ecological contexts. The high level of diversification in smallholder agricultural production also poses an important challenge analytically. Context-specific prospective and strategic planning of agricultural investments is still a largely underdeveloped aspect of quantitative foresight work.

We can, however, summarize our findings from the analysis of foresight studies related to agricultural income and employment in four key insights which we discuss below.

Insight 1: Investments in agricultural research to close the yield gap in developing countries are projected to generate future benefits of about USD 7 trillion in 2050, mostly in Asia. Complementary investments that improve infrastructure and natural resource management increase the global estimate to nearly USD 10 trillion. Investments that lower costs of getting farm produce to market could lead to the largest gains in per capita incomes in Latin America and sub-Saharan Africa.

According to the papers reviewed in this work, agricultural research targeting productivity enhancement is projected to have a positive effect on future income gains to the extent of 8.8 trillion USD in developing countries, and on employment creation in Africa (compared to other infrastructure investments)). Agricultural research has been projected to help lift 2.3 million people annually out of poverty in various sub-Saharan African and South Asian countries (. For example, the adoption of improved rice varieties help lift 8 million persons out of poverty and food insecurity in SSA .

This review also highlights the importance of considering the macro-economic contexts of countries when doing sectoral foresight studies about agricultural technologies, income and poverty. Economic structures, performances of institutions, welfare reallocation mechanisms, and other macroeconomic parameters can be instrumental in generating expected impact of agricultural modernization through intensive technology adoption and financial solutions in the poorest developing countries.

Rural transformation, a major driver affecting overall agriculture development, in combination with population growth and migration opportunities, has the potential to affect farm size and this will, in turn, continue to modify the opportunity space within agri-food systems.

Insight 2: Emerging evidence suggests that trends towards increasing numbers of medium size farms in Africa will continue going forward into the future, with 
potentially major implications (both in positive and negative sense) for agricultural technology adoption, urbanization and labor demand.

At the same time, further fragmentation of land will limit income generation options on small farms and in turn likely cause increased pressures on cities and the need to provide more income options outside agriculture. Studies in Africa indicate that intensifying land scarcity is expected to increase rural-rural migration to areas where land is still available and put greater pressure on non-farm sectors to absorb rural labor in densely populated areas. The increase in medium-size farms in Africa can be the result of land consolidation as well as movement into new land. The role of these two different forces requires more research with special emphasis on the political economic aspects of these processes.

Rural transformation processes are themselves complex in nature and drive employment opportunities and changing livelihood strategies. We observe migration and changes in structural decisions around "hanging-in", "stepping-up" or "moving-out" to use the terminology of (.

The debate on farm size, investment in land and the link to livelihood strategies is far from over and a key component of the rural transformation discussion. Revisiting the "hanging-in, movingup or moving out" analysis in a foresight context is essential in the preparation of future-proof policies and priority setting for agricultural R\&D that will lead to technologies that come to fruition in the future.

Diversification of livelihood strategies into activities outside the farm enterprise remains a complex process. There are both push and pull effects, often in combination. Pushed because of too many people for the land size (population pressure) or adverse weather pushes people to look for work elsewhere, or pulled as more educated or general development means more opportunities off-farm. Further research is needed to determine what consequences this has for technology demand as agriculture itself is intensified.

Insight 3: Rural households in South Asia and sub-Saharan Africa will follow trends observed in East Asia and Latin America towards increasing diversification of livelihoods, especially towards more non-farm work. Investment in infrastructure and human capital will be needed to make sure opportunities for increased incomes and employment are inclusive.

Livelihood diversification is closely associated, for instance, with rural transformation and urbanization, as a result of rural outmigration. In developing countries, rural transformation will likely take place within the realms of cereal-based agri-food systems, as these will likely prevail until 2050 As part of the rural transformation, urbanization holds the potential to reduce income inequality in the future, but simultaneously may worsen food insecurity for the resource-poor and negatively affect natural resources.

Youth unemployment is a major issue globally (Ripoll et al. 2017). Gender and youth were both recently highlighted as the biggest gaps in foresight during a commissioned ISDC review on the topic (Lentz 2021).

Of the many global dynamics, digitalization of agriculture is a potential game-changer for agrifood systems in low and middle-income countries. Based on this, there is a quickly expanding set of activities related to digitalization of agriculture within the CGIAR. Examples include 
the Platform for Big Data, the technology innovation hub, $\underline{\text { I-Hub }}$ at ICRISAT, the Ecosystem of Entrepreneurship at the SERVIR Amazonia Hub at CIAT and the nascent testing and learning platform for digital trust and transparency technologies AgriFoodTrust coordinated by CIMMYT.

Insight 4: Digital and other information-based innovations will have very large impacts on production and value chains in some food systems, possibly leaving some key stakeholders behind. This may have mixed effects on consumers and the environment, but will likely accelerate the divergence between large-scale commercial producers and small-scale producers and workers, unless the process of digitalization is made truly inclusive.

The digitalization of agriculture is already taking place across the world including the developing regions, and the potential for using digital technologies to transform agri-food systems is recognized. Digitalization of agriculture as part of livelihood strategies of the resource-poor depends critically on markets and service provision, enabling policies and institutional arrangements more than on technology itself). Digitalization of agri-food systems will play an increasingly important role in finance and extension services, markets and value chains, safety nets and risk mitigation strategies. Hence, it has a potentially profound impact on agricultural income and employment. Digital technologies are not inherently neutral and can either close or widen social divides between men and women, age groups and other social constructs. There are knowledge gaps in this domain inherent with the rapidly changing landscape. Future research on smallholders' financing options within the CGIAR should cover a wide range of issues from the traditional research on access to finance, to work pioneering the adoption of satellite technology in the design of financial products for agricultural producers in remote or otherwise marginalized locations, and the adoption of other digital solutions.

The key insights presented above depend critically on external drivers shaping the resource endowments available for our stakeholders to adapt their livelihood strategies to new circumstances. The drivers and pressures shape the functioning of markets and value chains and the availability of technology solutions.

Additional prospective studies are also needed on the contribution of gender to agricultural labor, effect of seasonality and stability of agricultural employment for men and women labor, etc. In-depth analysis of the labor market structure in agricultural and rural areas will be needed to enhance the prioritization of future investments towards increased stability and inclusion of employment. These studies will need to be both global and more local (e.g., country level). Human capital is essential in the processes of rural transformation. The ability of resource poor target beneficiaries of CGIAR to take advantage of on-farm innovation, off-farm employment, income diversification, the digitalization of agri-food systems to improve resilience to shocks, as well as to enhance income and employment levels in an inclusive way. Better understanding of the potential future impact of specific investments in human capital as an enabler for rural and agricultural development is therefore essential. Increasing incomes and employment in rural areas require resilient and efficient agricultural value chains characterized by sustained demand for agricultural produce, reduced marketing costs, good governance, and enhanced engagement with the broader economy. With regards to future demand for agricultural commodities from 
agri-food systems, research could be used to identify country-tailored retail modernization approaches that guarantee food safety for urban masses while enhancing rural employment and incomes. Regarding marketing costs, research could help identify key bottlenecks that raise costs across agricultural value chains. In addition, post-harvest losses for some crops can be reduced through both breeding and post-harvest measures and research should be used to identify the most cost-effective mix of approaches required to minimize post-harvest losses for staple food crops.

On good governance cross value chains, it would be important to identify contracting mechanisms required to ensure that processors can receive steady, uniform and quality produce from farmers, especially targeting the poorest segments of the producers. More specifically, research can be used to assess and identify adequate governance mechanisms for the complex agricultural value chains found in the developing world (across countries and regions. For agrifood systems to be well integrated with other economic sectors and lead to enhanced rural incomes and employment, research could identify the prerequisites and mechanisms required to facilitate inclusive rural transformation across the developing world. Regarding shocks which usually occur without warning and can have devastating effects in confined locations or globally, research can be used to support the development of early warning systems along with mechanisms to reduce risks and minimize harmful effects for agri-food value chains. 


\section{References}

Acharya, S.K., K. Pradhan, P. Choudhuri, and A.B. Sharangi. 2015. "Introduction." In Value Addition of Horticultural Crops: Recent Trends and Future Directions, 1-12. https://doi.org/10.1007/978-81322-2262-0_1.

Acheampong, Emmanuel Opoku, Jeffrey Sayer, and Colin J. Macgregor. 2018. "Road Improvement Enhances Smallholder Productivity and Reduces Forest Encroachment in Ghana." Environmental Science and Policy 85. https://doi.org/10.1016/j.envsci.2018.04.001.

Adamopoulos, Tasso, and Diego Restuccia. 2014. "The Size Distribution of Farms and International Productivity Differences." American Economic Review 104 (6): 1667-97. https://doi.org/10.1257/aer.104.6.1667.

Adetutu, Morakinyo O., and Victor Ajayi. 2020. "The Impact of Domestic and Foreign R\&D on Agricultural Productivity in Sub-Saharan Africa." World Development 125 (January): 104690. https://doi.org/10.1016/j.worlddev.2019.104690.

African Union. 2014. "Malabo Declaration on Accelerated Agricultural Growth and Transformation for Shared Prosperity and Improved Livelihoods." African Union: Malabo, Guinea Bissau, 2015061217.

AGRF. 2019. "Leveraging Digital Transformation to Drive Sustainable Food Systems in Africa." https://agrf.org/wp-content/uploads/2020/02/AGRF19-Report-2019_Compressed.pdf.

Alae-Carew, Carmelia, Frances A. Bird, Samira Choudhury, Francesca Harris, Lukasz Aleksandrowicz, James Milner, Edward JM Joy, Sutapa Agrawal, Alan D. Dangour, and Rosemary Green. 2019. "Future Diets in India: A Systematic Review of Food Consumption Projection Studies." Global Food Security. https://doi.org/10.1016/j.gfs.2019.05.006.

Alene, Arega D., and Ousmane Coulibaly. 2009. "The Impact of Agricultural Research on Productivity and Poverty in Sub-Saharan Africa." Food Policy 34 (2): 198-209.

https://doi.org/http://dx.doi.org/10.1016/j.foodpol.2008.10.014.

Alene, Arega D., Abebe Menkir, S. O. Ajala, B. Badu-Apraku, A. S. Olanrewaju, V. M. Manyong, and Abdou Ndiaye. 2009. "The Economic and Poverty Impacts of Maize Research in West and Central Africa." Agricultural Economics 40 (5). https://doi.org/10.1111/j.1574-0862.2009.00396.x.

Amarnath, Giriraj, Surajit Ghosh, Niranga Alahacoon, Shirish Kumar Ravan, P.K. Taneja, Nisarg Dave, and Sanjay K. Srivastava. 2019. "Insurance as an Agricultural Disaster Risk Management Tool: Evidence and Lessons Learned from South Asia." United Nations Economic and Social Commission for Asia and the Pacific. https://cgspace.cgiar.org/handle/10568/106053.

Arndt, Channing, Henning Tarp Jensen, Sherman Robinson, and Finn Tarp. 2000. "Marketing Margins and Agricultural Technology in Mozambique." The Journal of Development Studies 37 (1): 121-37.

Arouna, A., J. C. Lokossou, M. C.S. Wopereis, S. Bruce-Oliver, and H. Roy-Macauley. 2017. "Contribution of Improved Rice Varieties to Poverty Reduction and Food Security in Sub-Saharan Africa." Global Food Security 14. https://doi.org/10.1016/j.gfs.2017.03.001.

Balana, Bedru B., Jean Claude Bizimana, James W. Richardson, Nicole Lefore, Zenebe Adimassu, and Brian K. Herbst. 2020. "Economic and Food Security Effects of Small-Scale Irrigation Technologies in Northern Ghana." Water Resources and Economics 29 (January): 100141. 
https://doi.org/10.1016/J.WRE.2019.03.001.

Baltenweck, Isabelle, Dolapo Enahoro, Aymen Frija, and Shirley Tarawali. 2020. "Why Is Production of Animal Source Foods Important for Economic Development in Africa and Asia?" Animal Frontiers 10 (4). https://doi.org/10.1093/af/vfaa036.

Barrett, Christopher B. 2020. "On Research Strategy for the New One CGIAR: Editor's Introduction." Food Policy 91 (February): 101844. https://doi.org/10.1016/J.FOODPOL.2020.101844.

Bennett, Aoife, Ashwin Ravikumar, Constance McDermott, and Yadvinder Malhi. 2019. "Smallholder Oil Palm Production in the Peruvian Amazon: Rethinking the Promise of Associations and Partnerships for Economically Sustainable Livelihoods." Frontiers in Forests and Global Change 2 (April). https://doi.org/10.3389/FFGC.2019.00014.

Berger, T., C. Troost, T. Wossen, E. Latynskiy, K. Tesfaye, and S. Gbegbelegbe. 2017. “Can Smallholder Farmers Adapt to Climate Variability, and How Effective Are Policy Interventions? Agent-Based Simulation Results for Ethiopia." Agricultural Economics (United Kingdom). https://doi.org/10.1111/agec.12367.

Boffa, Mauro, Marion Jansen, and Olga Solleder. 2021. "Participating to Compete: Do Small Firms in Developing Countries Benefit from Global Value Chains?" Economies 2021, Vol. 9, Page 129 (1): 12. https://doi.org/10.3390/ECONOMIES9010012.

Brauw, Alan De. 2019. "Migration out of Rural Areas and Implications for Rural Livelihoods." Annual Review of Resource Economics. https://doi.org/10.1146/annurev-resource-100518-093906.

Cairns, Jill E., Jon Hellin, Kai Sonder, Jos?? Luis Araus, John F. MacRobert, Christian Thierfelder, and B. M. Prasanna. 2013. "Adapting Maize Production to Climate Change in Sub-Saharan Africa." Food Security 5: 345-60. https://doi.org/10.1007/s12571-013-0256-x.

Carter, Rebecca, Namrata Ginoya, Richard Choularton, Tyler Ferdinand, Helen Ding, and Parvathi Preethan. 2021. Food Systems at Risk: Transformative Adaptation for Long-Term Food Security. World Resources Institute. https://doi.org/10.46830/wrirpt.19.00042.

Chenery, Hollis Burnley, Moises Syrquin, and Hazel Elkington. 1975. Patterns of Development, 19501970. Vol. 75. Oxford University Press London.

Chung, Uran, Sika Gbegbelegbe, Bekele Shiferaw, Richard Robertson, Jin I. Yun, Kindie Tesfaye, Gerrit Hoogenboom, and Kai Sonder. 2014. "Modeling the Effect of a Heat Wave on Maize Production in the USA and Its Implications on Food Security in the Developing World." Weather and Climate Extremes 5-6: 67-77. https://doi.org/10.1016/j.wace.2014.07.002.

Collier, Paul, and Stefan Dercon. 2014. "African Agriculture in 50Years: Smallholders in a Rapidly Changing World?" World Development 63: 92-101. https://doi.org/https://doi.org/10.1016/j.worlddev.2013.10.001.

CTA. 2019. The Digitalisation of African Agriculture Report 2018-2019. African Affairs. https://doi.org/10.1093/oxfordjournals.afraf.a094187.

Dantwala, M.L. 1989. "Estimates of Demand for Credit and Its Role in Poverty Alleviation." Indian Journal of Agricultural Economics 44 (4): 416-22.

Dawe, David, Steven Jaffee, and Nuno Santon. 2014. "Rice, Climate Change and Adaptation Options." 
Rice in the Shadow of Skyscrapers: Policy Choices in a Dynamic East and Southeast Asian Setting. Rome.

Dawe, David, and C Peter Timmer. 2012. "Why Stable Food Prices Are a Good Thing: Lessons from Stabilizing Rice Prices in Asia." Global Food Security 1 (2): 127-33.

Deryng, Delphine, Declan Conway, Navin Ramankutty, Jeff Price, and Rachel Warren. 2014. "Global Crop Yield Response to Extreme Heat Stress under Multiple Climate Change Futures." Environmental Research Letters 9 (3): 034011. https://doi.org/10.1088/1748-9326/9/3/034011.

Desiere, Sam, Yung Hung, Wim Verbeke, and Marijke D’Haese. 2018. “Assessing Current and Future Meat and Fish Consumption in Sub-Sahara Africa: Learnings from FAO Food Balance Sheets and LSMS Household Survey Data." Global Food Security. https://doi.org/10.1016/j.gfs.2017.12.004.

Devaux, Andre, Maximo Torero, Jason Donovan, and Douglas Horton. 2018. "Agricultural Innovation and Inclusive Value-Chain Development: A Review." Journal of Agribusiness in Developing and Emerging Economies.

Dillon, Brian, and Christopher B. Barrett. 2017. "Agricultural Factor Markets in Sub-Saharan Africa: An Updated View with Formal Tests for Market Failure." Food Policy 67. https://doi.org/10.1016/j.foodpol.2016.09.015.

Dolapo Enahoro, Kumar Shalander, and Karl M. Rich. 2021. "Market Competitiveness and the Future of West African Cattle and Beef Value Chains." 103. ILRI Research Brief. Nairobi, Kenya: International Livestock Research Institute (ILRI). https://cgspace.cgiar.org/bitstream/handle/10568/116930/research_brief_103.pdf?sequence=3\&i sAllowed=y.

Dorward, Andrew, Simon Anderson, Yolanda Nava Bernal, Ernesto Sánchez Vera, Jonathan Rushton, James Pattison, and Rodrigo Paz. 2009. "Hanging in, Stepping up and Stepping out: Livelihood Aspirations and Strategies of the Poor." Development in Practice. https://doi.org/10.1080/09614520802689535.

Duku, Confidence, Adam H. Sparks, and Sander J. Zwart. 2016. "Spatial Modelling of Rice Yield Losses in Tanzania Due to Bacterial Leaf Blight and Leaf Blast in a Changing Climate." Climatic Change 135 (3): 569-83. https://doi.org/10.1007/s10584-015-1580-2.

Dumas, Patrice, Craig Hanson, Janet Ranganathan, Tim Searchinger, and Richard Waite. 2019. Creating a Sustainable Food Future. WRI - World Resources Institute. Vol. 1. https://research.wri.org/sites/default/files/2019-07/WRR_Food_Full_Report_0.pdf.

Dzanku, Fred M, Magnus Jirström, and Håkan Marstorp. 2015. "Yield Gap-Based Poverty Gaps in Rural Sub-Saharan Africa." World Development 67: 336-62. https://doi.org/https://doi.org/10.1016/j.worlddev.2014.10.030.

Ebi, K.L., J. Padgham, M. Doumbia, A. Kergna, J. Smith, T. Butt, and B. McCarl. 2011. "Smallholders Adaptation to Climate Change in Mali." Climatic Change 108 (3): 423-36. https://doi.org/10.1007/s10584-011-0160-3.

Ellis, Frank. 1998. "Household Strategies and Rural Livelihood Diversification." Journal of Development Studies 35 (1): 1-38. https://doi.org/10.1080/00220389808422553.

Enahoro, D, N Njiru, P Thornton, and SJ Staal. 2019. "A Review of Projections of Demand and Supply of 
Livestock-Derived Foods and the Implications for Livestock Sector Management in LSIL Focus Countries." 262. CCAFS Working Paper. Wageningen, The Netherlands.

https://ccafs.cgiar.org/resources/publications/review-projections-demand-and-supply-livestockderived-foods-and.

Enahoro, Dolapo, Mats Lannerstad, Catherine Pfeifer, and Paula Dominguez-Salas. 2018. "Contributions of Livestock-Derived Foods to Nutrient Supply under Changing Demand in Low- and Middle-Income Countries." Global Food Security 19 (December): 1-10. https://doi.org/10.1016/J.GFS.2018.08.002.

Enahoro, Dolapo, Daniel Mason-D’Croz, Marloes Mul, Karl M. Rich, Timothy P. Robinson, Philip Thornton, and Steven S. Staal. 2019. "Supporting Sustainable Expansion of Livestock Production in South Asia and Sub-Saharan Africa: Scenario Analysis of Investment Options." Global Food Security. https://doi.org/10.1016/j.gfs.2019.01.001.

Evenson, R. E., and D. Gollin. 2003a. "Assessing the Impact of the Green Revolution, 1960 to 2000." Science. https://doi.org/10.1126/science.1078710.

- - . 2003b. "Assessing the Impact of the Green Revolution, 1960 to 2000." Science 300 (5620): 758 LP - 762. https://doi.org/10.1126/science.1078710.

Fan, Shenggen, Joanna Brzeska, Michiel Keyzer, and Alex Halsema. 2013. From Subsistence to Profit: Transforming Smallholder Farms. Vol. 26. Intl Food Policy Res Inst.

FAO. 2019. The State of Food and Agriculture: Moving Forward on Food Loss and Waste Reduction. Rome, Italy: Food and Agriculture Organization of the United Nations. https://www.fao.org/publications/sofa/2019/en/.

- - . 2020. Beyond Regulatory Compliance, Seafood Traceability Benefits and Success Cases. Rome, Italy: FAO. https://www.fao.org/3/ca9550en/ca9550en.pdf.

- - - 2021. The State of Food and Agriculture 2021. Rome, Italy: Food and Agriculture Organization of the United Nations. https://doi.org/10.4060/CB4476EN.

Fouré, Jean, Agnès Bénassy-Quéré, and Lionel Fontagné. 2013. "Modelling the World Economy at the 2050 Horizon." Economics of Transition. https://doi.org/10.1111/ecot.12023.

Frija, Aymen, Ali Chebil, Khondoker Abdul Mottaleb, Daniel Mason-D'Croz, and Boubaker Dhehibi. 2020. "Agricultural Growth and Sex-Disaggregated Employment in Africa: Future Perspectives under Different Investment Scenarios." Global Food Security 24. https://doi.org/10.1016/j.gfs.2020.100353.

Fuglie, Keith, Madhur Gautam, Aparajita Goyal, and William F. Maloney. 2019. Harvesting Prosperity: Technology and Productivity Growth in Agriculture. License: C. Washington, DC: The World Bank. https://doi.org/10.1596/978-1-4648-1393-1.

Galinha, Catarina, María Sánchez-Martínez, Adriano M G Pacheco, Maria do Carmo Freitas, José Coutinho, Benvindo Maçãs, Ana Sofia Almeida, María Teresa Pérez-Corona, Yolanda Madrid, and Hubert T. Wolterbeek. 2014. "Characterization of Selenium-Enriched Wheat by Agronomic Biofortification." Journal of Food Science and Technology. https://doi.org/10.1007/s13197-0141503-7.

Gassner, A, D Harris, K Mausch, A Terheggen, C Lopes, RF Finlayson, and P Dobie. 2019. "Poverty Eradication and Food Security through Agriculture in Africa: Rethinking Objectives and Entry 
Points." Outlook on Agriculture 48 (4): 309-15. https://doi.org/10.1177/0030727019888513.

Gatto, Marcel, Athanasios Petsakos, and Guy Hareau. 2020. "Sustainable Intensification of Rice-Based Systems with Potato in Eastern Indo-Gangetic Plains." American Journal of Potato Research 97 (2): 162-74. https://doi.org/10.1007/s12230-020-09764-6.

Gbegbelegbe, Sika, Uran Chung, Bekele Shiferaw, Siwa Msangi, and Kindie Tesfay. 2014. "Quantifying Theimpactofweatherextremesonglobalfoodsecurity: A Spatialbio-Economicapproach." WeatherandClimateExtremes 4: 97-108. http://crossmark.crossref.org/dialog/?doi=10.1016/j.wace.2014.05.005\&domain=pdf.

Gbegbelegbe, Sika, Jared Serem, Clare Stirling, Florence Kyazze, Maren Radeny, Michael Misiko, Songporne Tongruksawattana, Lydia Nafula, Mercy Gakii, and Kai Sonder. 2017. "Smallholder Farmers in Eastern Africa and Climate Change: A Review of Risks and Adaptation Options with Implications for Future Adaptation Programmes." Climate and Development 10 (4): 289-306. https://doi.org/10.1080/17565529.2017.1374236.

George, Thomas. 2014. "Why Crop Yields in Developing Countries Have Not Kept Pace with Advances in Agronomy." Global Food Security. https://doi.org/10.1016/j.gfs.2013.10.002.

Gollin, Douglas, and Richard Rogerson. 2010. "Agriculture, Roads, and Economic Development in Uganda." National Bureau of Economic Research.

Govaerts, B., X. Chávez, A. Fernández, D. Vega, O. Vázquez, M. Pérez, A. Carvajal, et al. 2019. Maíz Para México. Edited by Rebeca López Perea. Texcoco: CIMMYT. https://repository.cimmyt.org/handle/10883/20219.

Habtemariam, L.T., M. Gandorfer, G.A. Kassa, and A. Heissenhuber. 2016. "Factors Influencing Smallholder Farmers' Climate Change Perceptions: A Study from Farmers in Ethiopia." Environmental Management 58 (2): 343-58. https://doi.org/10.1007/s00267-016-0708-0.

Harris, D. 2019. "Intensification Benefit Index: How Much Can Rural Households Benefit from Agricultural Intensification?" Experimental Agriculture. https://doi.org/10.1017/S0014479718000042.

Harris, David, and Alastair Orr. 2014. "Is Rainfed Agriculture Really a Pathway from Poverty?" Agricultural Systems. https://doi.org/10.1016/j.agsy.2013.09.005.

Hermans, Frans, Fabio Chaddad, Taras Gagalyuk, Sebastian Senesi, and Alfons Balmann. 2017. "The Emergence and Proliferation of Agroholdings and Mega Farms in a Global Context." International Food and Agribusiness Management Review 20 (2): 175-86.

IFAD. 2016. "Rural Development Report 2016." Rome. https://www.ifad.org/documents/30600024/30604583/RDR_WEB.pdf/c734d0c4-fbb1-4507-9b4b$6 \mathrm{c} 432 \mathrm{c} 6 \mathrm{f} 38 \mathrm{c} 3$.

- - . 2019. "Rural Development Report: Creating Opportunities for Rural Youth." Rome, Italy: IFAD. https://www.ifad.org/en/web/knowledge/-/publication/2019-rural-development-report.

- - - 2021. "Rural Development Report: Transforming Food Systems for Rural Prosperity." Rural Development Report 2021.

IPCC. 2019. "Climate Change and Land (Approved Draft)." Geneva. https://www.ipcc.ch/report/srccl/. 
Ittersum, Martin K. Van, Lenny G.J. Van Bussel, Joost Wolf, Patricio Grassini, Justin Van Wart, Nicolas Guilpart, Lieven Claessens, et al. 2016. "Can Sub-Saharan Africa Feed Itself?" Proceedings of the National Academy of Sciences of the United States of America 113 (52): 14964-69. https://doi.org/10.1073/PNAS.1610359113/-/DCSUPPLEMENTAL.

Jabbar, Mohammad, Steve Staal, John McIntire, and Simeon Ehui. 2020. "Economics and Policy Research at ILRI, 1975-2018." In The Impact of the International Livestock Research Institute. https://doi.org/10.1079/9781789241853.0639.

Janvry, Alain de, and Elisabeth Sadoulet. 2020. "Using Agriculture for Development: Supply- and Demand-Side Approaches." World Development. https://doi.org/10.1016/j.worlddev.2020.105003.

Jayne, T. S., Jordan Chamberlin, and Derek D. Headey. 2014. "Land Pressures, the Evolution of Farming Systems, and Development Strategies in Africa: A Synthesis." Food Policy 48: 1-17.

Karnani, Aneel, and Kevin McKague. 2014. "Job Creation in the Mozambican Poultry Industry." European Financial Review, 2014. http://www.europeanfinancialreview.com/job-creation-mozambicanpoultry-industry/.

Kiambi, Stella, Joshua Orungo Onono, Erastus Kang'ethe, Gabriel O. Aboge, Maurice K. Murungi, Patrick Muinde, James Akoko, et al. 2020. "Investigation of the Governance Structure of the Nairobi Dairy Value Chain and Its Influence on Food Safety." Preventive Veterinary Medicine 179 (June): 105009. https://doi.org/10.1016/J.PREVETMED.2020.105009.

Kilby, Peter, and Bruce F Johnston. 1975. Agriculture and Structural Transformation: Economic Strategies in Late-Developing Countries. Oxford University Press London.

Kislev, Yoav, and Willis Peterson. 1982. "Prices, Technology, and Farm Size." Journal of Political Economy 90 (3): 578-95.

Komarek, Adam M., Sophie Drogue, Roza Chenoune, James Hawkins, Siwa Msangi, Hatem Belhouchette, and Guillermo Flichman. 2017. "Agricultural Household Effects of Fertilizer Price Changes for Smallholder Farmers in Central Malawi." Agricultural Systems 154: 168-78. https://doi.org/https://doi.org/10.1016/j.agsy.2017.03.016.

Komarek, Adam M., and Siwa Msangi. 2019. "Effect of Changes in Population Density and Crop Productivity on Farm Households in Malawi." Agricultural Economics (United Kingdom). https://doi.org/10.1111/agec.12513.

Kramer, Berber, Francisco Ceballos, Matthew Krupoff, Mann S Toor, Azad Mishra, Siddesh Karekar, and Miguel Robles. 2017. "Picture-Based Insurance: Is It Sustainable? Effects on Willingness to Pay, Adverse Selection, and Moral Hazard."

Krishna, Vijesh, Michael Euler, Hermanto Siregar, and Matin Qaim. 2017. "Differential Livelihood Impacts of Oil Palm Expansion in Indonesia." Agricultural Economics 48 (5): 639-53. https://doi.org/10.1111/AGEC.12363.

Kruseman, Gideon, Subir Bairagi, Adam M. Komarek, Anabel Molero Milan, Swamikannu Nedumaran, Athanasios Petsakos, Steven Prager, and Yigezu A. Yigezu. 2020. "CGIAR Modeling Approaches for Resource-Constrained Scenarios: II. Models for Analyzing Socioeconomic Factors to Improve Policy Recommendations." Crop Science 60 (2): 568-81. https://doi.org/10.1002/csc2.20114.

Kruseman, Gideon, Khondoker Abdul Mottaleb, Kindie Tesfaye, Subir Bairagi, Richard Robertson, Diagne 
Mandiaye, Aymen Frija, Sika Gbegbelegbe, Arega D. Alene, and Steven D Prager. 2020. "Rural Transformation and the Future of Cereal-Based Agri-Food Systems." Global Food Security 26. https://doi.org/10.1016/j.gfs.2020.100441.

Kubitza, Christoph, Vijesh V. Krishna, Zulkifli Alamsyah, and Matin Qaim. 2018. "The Economics Behind an Ecological Crisis: Livelihood Effects of Oil Palm Expansion in Sumatra, Indonesia." Human Ecology 46 (1): 107-16. https://doi.org/10.1007/S10745-017-9965-7/FIGURES/3.

Kuiper, M., L. Shutes, H. van Meijl, D. Oudendag, and A. Tabeau. 2019. "Labor Supply Assumptions - A Missing Link in Food Security Projections." Global Food Security. https://doi.org/10.1016/j.gfs.2019.100328.

Lantican, M., Hans-Joachim Braun, Thomas S Payne, RP Singh, Kai Sonder, M Baum, M Van Ginkel, and O Erenstein. 2016. Impacts of International Wheat Improvement Research, 1994-2014. Texcoco: CIMMYT.

Larson, Donald F, Rie Muraoka, and Keijiro Otsuka. 2016. "On the Central Role of Small Farms in African Rural Development Strategies." WPS7710. Washington D.C. https://doi.org/10.1016/j.gfs.2016.07.006.

Lee, Joonkoo, Gary Gereffi, and Janet Beauvais. 2012. "Global Value Chains and Agrifood Standards: Challenges and Possibilities for Smallholders in Developing Countries." Proceedings of the National Academy of Sciences 109 (31): 12326-31. https://doi.org/10.1073/PNAS.0913714108.

Lentz, Erin C. 2021. "Food and Agriculture Systems Foresight Study: Implications for Gender, Poverty, and Nutrition." Q Open 1 (1). https://doi.org/10.1093/qopen/qoaa003.

Li, Jintao, Yansui Liu, Yuanyuan Yang, and Ning Jiang. 2019. “County-Rural Revitalization Spatial Differences and Model Optimization in Miyun District of Beijing-Tianjin-Hebei Region." Journal of Rural Studies.

Loboguerrero, Ana Maria, James Birch, Phillip Thornton, Laura Meza, Ishmael Sunga, Bui Ba Bong, Rudy Rabbinge, et al. 2018. "Feeding the World in a Changing Climate: An Adaptation Roadmap for Agriculture." Glob. Comm. Adapt.

MacDonald, James M, Penni Korb, and Robert A Hoppe. 2013. "Farm Size and the Organization of US Crop Farming."

Marchi, Valentina De, Elisa Giuliani, and Roberta Rabellotti. 2018. "Do Global Value Chains Offer Developing Countries Learning and Innovation Opportunities?" European Journal of Development Research 30 (3). https://doi.org/10.1057/s41287-017-0126-z.

Maredia, Mywish K., and David a. Raitzer. 2012. "Review and Analysis of Documented Patterns of Agricultural Research Impacts in Southeast Asia." Agricultural Systems 106 (1): 46-58. https://doi.org/10.1016/j.agsy.2011.10.011.

Marwaha, R. S., S. K. Pandey, Dinesh Kumar, S. V. Singh, and Parveen Kumar. 2010. "Potato Processing Scenario in India: Industrial Constraints, Future Projections, Challenges Ahead and Remedies - A Review." Journal of Food Science and Technology. https://doi.org/10.1007/s13197-010-0026-0.

Mason-D'Croz, Daniel, Timothy B. Sulser, Keith Wiebe, Mark W. Rosegrant, Sarah K. Lowder, Alejandro Nin-Pratt, Dirk Willenbockel, et al. 2019. "Agricultural Investments and Hunger in Africa Modeling Potential Contributions to SDG2 - Zero Hunger." World Development. 
https://doi.org/10.1016/j.worlddev.2018.12.006.

Michler, Jeffrey D. 2020. "Agriculture in the Process of Development: A Micro-Perspective." World Development 129 (May): 104888. https://doi.org/10.1016/J.WORLDDEV.2020.104888.

Minot, Nicholas, and Rachel Huang. 2019. "Distributional Effects of Higher Cassava Yields in Nigeria: An Ex Ante Analysis." 1901. IFPRI Discussion Paper. Washington D.C., USA. https://doi.org/10.2499/p15738coll2.133548.

Minot, Nicholas, Harold Glenn Valera, and Jean Balié. 2021. "Prioritization of Agricultural Research for Poverty Impact: An Application to the Philippines." In American Association of Agricultural Economics. Austin, Texas, USA. https://ageconsearch.umn.edu/record/313976/files/Abstracts_21_06_15_19_52_12_00_172_58 _43_249_0.pdf.

Minten, Bart, Yetimwork Habte, Seneshaw Tamru, and Agajie Tesfaye. 2020. "The Transforming Dairy Sector in Ethiopia." PLOS ONE 15 (8 August). https://doi.org/10.1371/journal.pone.0237456.

Minten, Bart, Seneshaw Tamru, and Thomas Reardon. 2020. "Post-Harvest Losses in Rural-Urban Value Chains: Evidence from Ethiopia." Food Policy, 101860.

Mishra, Pradeep Kumar, and Kushankur Dey. 2018. "Governance of Agricultural Value Chains: Coordination, Control and Safeguarding." Journal of Rural Studies 64 (November): 135-47. https://doi.org/10.1016/J.JRURSTUD.2018.09.020.

Montalbano, Pierluigi, Silvia Nenci, and Carlo Pietrobelli. 2018. "Opening and Linking up: Firms, GVCs, and Productivity in Latin America." Small Business Economics 50 (4): 917-35. https://doi.org/10.1007/S11187-017-9902-6/TABLES/7.

Mottaleb, K.A., A. Loladze, K. Sonder, G. Kruseman, and F. San Vicente. 2019. "Threats of Tar Spot Complex Disease of Maize in the United States of America and Its Global Consequences." Mitigation and Adaptation Strategies for Global Change 24 (2). https://doi.org/10.1007/s11027018-9812-1.

Mottaleb, Khondoker A., Roderick M. Rejesus, Mvr Murty, Samarendu Mohanty, and Tao Li. 2017. "Benefits of the Development and Dissemination of Climate-Smart Rice: Ex Ante Impact Assessment of Drought-Tolerant Rice in South Asia." Mitigation and Adaptation Strategies for Global Change 22 (6): 879-901. https://doi.org/10.1007/s11027-016-9705-0.

Mottaleb, Khondoker Abdul, Pawan Kumar Singh, Kai Sonder, Gideon Kruseman, Thakur Prasad Tiwari, N.C.D. Barma, Paritosh Kumar Malaker, Hans-Joachim Braun, and Olaf Erenstein. 2018. "Threat of Wheat Blast to South Asia's Food Security: An Ex-Ante Analysis." Edited by Wujun Ma. Plos One 13 (5). https://doi.org/10.1371/journal.pone.0197555.

Moyo, Sibusiso, George W. Norton, Jeffrey Alwang, Ingrid Rhinehart, and Michael Deom. 2007. "Peanut Research and Poverty Reduction: Impacts of Variety Improvement to Control Peanut Viruses in Uganda." American Journal of Agricultural Economics 89 (2). https://doi.org/10.1111/j.14678276.2007.00991.x.

Mueller, Valerie, and James Thurlow. 2019. Youth and Jobs in Rural Africa: Beyond Stylized Facts. Oxford University Press.

Ncube, J, and M Maphosa. 2020. "Current State of Knowledge on Groundnut Aflatoxins and Their 
Management from a Plant Breeding Perspective: Lessons for Africa." Scientific African, e00264.

Nedumaran, S., Beleke Shiferaw, M. C S Bantilan, K. Palanisami, and Suhas P. Wani. 2014. "Bioeconomic Modeling of Farm Household Decisions for Ex-Ante Impact Assessment of Integrated Watershed Development Programs in Semi-Arid India." Environment, Development and Sustainability 16 (2): 257-86. https://doi.org/10.1007/s10668-013-9476-7.

Niroula, Gajendra S., and Gopal B. Thapa. 2005. "Impacts and Causes of Land Fragmentation, and Lessons Learned from Land Consolidation in South Asia." Land Use Policy 22 (4): 358-72. https://doi.org/10.1016/j.landusepol.2004.10.001.

OECD, and FAO. 2020. “OECD-FAO Agricultural Outlook 2020-2029." Paris, France. https://www.fao.org/publications/oecd-fao-agricultural-outlook/2020-2029/en/.

-- - 2021. “OECD-FAO Agricultural Outlook 2021-2030." OECD-FAO Agricultural Outlook. Paris, France: OECD. https://doi.org/10.1787/19991142.

Oostendorp, Remco, Marcel van Asseldonk, John Gathiaka, Richard Mulwa, Maren Radeny, John Recha, Cor Wattel, and Lia van Wesenbeeck. 2019. "Inclusive Agribusiness under Climate Change: A Brief Review of the Role of Finance." Current Opinion in Environmental Sustainability. https://doi.org/10.1016/j.cosust.2019.09.014.

Organization, CGIAR System. 2021. "CGIAR 2030 Research and Innovation Strategy: Transforming Food, Land, and Water Systems in a Climate Crisis." Montpellier, France. https://cgspace.cgiar.org/bitstream/handle/10568/110918/OneCGIAR-Strategy.pdf.

Otsuka, K, and D.E Larson. 2016. In Pursuit of an African Green Revolution. Edited by Keijiro Otsuka and Donald F. Larson. Tokyo: Springer Japan. https://doi.org/10.1007/978-4-431-55693-0.

Pacheco, Pablo, George Schoneveld, Ahmad Dermawan, Heru Komarudin, and Marcel Djama. 2020. "Governing Sustainable Palm Oil Supply: Disconnects, Complementarities, and Antagonisms between State Regulations and Private Standards." Regulation \& Governance 14 (3): 568-98. https://doi.org/10.1111/REGO.12220.

Peterman, Amber, Neha Kumar, Audrey Pereira, and Daniel O. Gilligan. 2019. "Towards Gender Equality A Review of Evidence on Social Safety Nets in Africa." IFPRI Discussion Paper. Washington DC.

Pinstrup-Andersen, P., and R. Pandya-Lorch. 1998. "Food Security and Sustainable Use of Natural Resources: A 2020 Vision." Ecological Economics 26 (1): 1-10. https://doi.org/10.1016/S09218009(97)00067-0.

Poulton, Colin, Jonathan Kydd, Steve Wiggins, and Andrew Dorward. 2006. "State Intervention for Food Price Stabilisation in Africa: Can It Work?" Food Policy 31 (4): 342-56.

Prager, Steven D., and Gideon Kruseman. 2021. "Projected Benefits CGIAR Research - Draft Report Prepared for CGIAR System Management Office." Montpellier.

Prager, Steven, Benjamin E. Schiek, Athanasios Petsakos, Gideon K. Kruseman, Sika Gbegbelegbe, Anne Terheggen, and Daniel Mason-D'Croz. 2021. "Thinking Big for Smallholder Agriculture: Realizing Agricultural Potentials in Changing Times." https://cgspace.cgiar.org/handle/10568/115144.

Raitzer, David A., and Timothy G. Kelley. 2008. "Benefit-Cost Meta-Analysis of Investment in the International Agricultural Research Centers of the CGIAR." Agricultural Systems 96 (1): 108-23. 
https://doi.org/10.1016/j.agsy.2007.06.004.

Raitzer, David a., and Mywish K. Maredia. 2012. "Analysis of Agricultural Research Investment Priorities for Sustainable Poverty Reduction in Southeast Asia." Food Policy 37 (4): 412-26. https://doi.org/10.1016/j.foodpol.2012.04.001.

Rao, Sumedh. 2012. "Employment Intensity of Growth in Agriculture." GSDRC Helpdesk Research Report. Birmingham, UK. https://doi.org/10.13140/RG.2.1.2099.5444.

Reardon, Thomas, and Julio A. Berdegué. 2008. "The Retail-Led Transformation of Agrifood Systems and Its Implications for Development Policies." World Development Report 2008 Background Paper, no. November, 2006.

Reardon, Thomas, Amir Heiman, Liang Lu, Chandra S.R. Nuthalapati, Rob Vos, and David Zilberman. 2021. "'Pivoting' by Food Industry Firms to Cope with COVID-19 in Developing Regions: ECommerce and 'Copivoting' Delivery Intermediaries." Agricultural Economics 52 (3): 459-75. https://doi.org/10.1111/AGEC.12631.

Renkow, Mitch, and Derek Byerlee. 2010. "The Impacts of CGIAR Research: A Review of Recent Evidence." Food Policy 35 (5): 391-402. https://doi.org/10.1016/j.foodpol.2010.04.006.

Rigo, Davide. 2021. "Global Value Chains and Technology Transfer: New Evidence from Developing Countries." Review of World Economics 157 (2): 271-94. https://doi.org/10.1007/S10290-02000398-8/TABLES/13.

Ripoll, Santiago, Jens Andersson, Lone Badstue, Marion Büttner, Jordan Chamberlin, Olaf Erenstein, and James Sumberg. 2017. "Rural Transformation, Cereals and Youth in Africa: What Role for International Agricultural Research?" Outlook on Agriculture. https://doi.org/10.1177/0030727017724669.

Rosegrant, Mark W., Timothy B. Sulser, Daniel Mason-D'Croz, Nicola Cenacchi, Alejandro Nin-Pratt, Shahnila Dunston, Tingju Zhu, et al. 2017. Quantitative Foresight Modeling to Inform the CGIAR Research Portfolio. USA: Intl Food Policy Res Inst. http://ebrary.ifpri.org/cdm/singleitem/collection/p15738coll2/id/131144.

Roza, Chenoune, Thomas Allen, Adam M. Komarek, Gomez y.Paloma Sergio, Flichman Guillermo, Capillon Alain, and Belhouchette Hatem. 2017. "Assessing Consumption-Production-Resources Nexus Decisions for Rice-Focused Agricultural Households in Sierra Leone." Land Use Policy 67: 597-607. https://doi.org/10.1016/j.landusepol.2017.06.014.

Ruyter de Wildt, Marieke de, Menno van Ginkel, Kirsten Coppoolse, Bart van Maarseveen, Jenny Walton, and Gideon K. Kruseman. 2019. "Blockchain For Food: Making Sense of Technology and the Impact on Biofortified Seeds." https://hdl.handle.net/10568/106615.

Santpoort, Romy. 2020. "The Drivers of Maize Area Expansion in Sub-Saharan Africa. How Policies to Boost Maize Production Overlook the Interests of Smallholder Farmers." Land 9 (3): 68. https://doi.org/10.3390/land9030068.

Scoones, Ian. 1998. "Sustainable Rural Livelihoods: A Framework for Analysis." https://opendocs.ids.ac.uk/opendocs/handle/20.500.12413/3390\#.YUiL7_BBeDI.mendeley.

Seneviratne, Sonia I., Neville Nicholls, David Easterling, Clare M. Goodess, Shinjiro Kanae, James Kossin, Yali Luo, et al. 2012. "Changes in Climate Extremes and Their Impacts on the Natural Physical 
Environment." In Managing the Risks of Extreme Events and Disasters to Advance Climate Change Adaptation, edited by C.B. Field, V. Barros, T.F. Stocker, D. Qin, D.J. Dokken, K.L. Ebi, M.D. Mastrandrea, et al., 109-230. Cambridge, UK, and New York, NY, USA: A Special Report of Working Groups I and II of the Intergovernmental Panel on Climate Change (IPCC).Cambridge University Press. https://doi.org/10.1017/CBO9781139177245.006.

Serraj, Rachid, and Prabhu Pingali. 2018. "Agriculture \&amp; Food Systems to 2050," World Scientific Series in Grand Public Policy Challenges of the 21st Century, 02 (December). https://doi.org/10.1142/11212.

Shapiro, Barry I., G. Gebru, S. Desta, Asfaw Negassa, K. Negussie, Gezahegn Aboset, and H. Mechal. 2015. "Ethiopia Livestock Master Plan: Roadmaps for Growth and Transformation." Nairobi, Kenya: Ministry of Agriculture and ILRI. https://cgspace.cgiar.org/handle/10568/68037.

Sharma, R. 2014. "Outlook for Rice Demand, Supply and Trade." In Rice in the Shadow of Skyscrapers: Policy Choices in a Dynamic East and Southeast Asian Setting, edited by D. Dawe, S. Jaffee, and N. Santos, 8-31. Rome, Italy: Food and Agriculture Organization of the United Nations.

Singh, M. 2010. "Projection of Potato Export from India: A Markov Chain Approach." Potato Journal 37 (1-2): 48-55.

Tanumihardjo, Sherry A., Laura McCulley, Rachel Roh, Santiago Lopez-Ridaura, Natalia Palacios-Rojas, and Nilupa S. Gunaratna. 2020. "Maize Agro-Food Systems to Ensure Food and Nutrition Security in Reference to the Sustainable Development Goals." Global Food Security. https://doi.org/10.1016/j.gfs.2019.100327.

Taye, Mintesinot, Belay Simane, Benjamin F. Zaitchik, Yihenew G. Selassie, and Shimelis Setegn. 2019. "Rainfall Variability across the Agro-Climatic Zones of a Tropical Highland: The Case of the Jema Watershed, Northwestern Ethiopia." Environments 2019, Vol. 6, Page 1186 (11): 118. https://doi.org/10.3390/ENVIRONMENTS6110118.

Tesfaye, Kindie, Gideon Kruseman, Jill E. Cairns, Mainassara Zaman-Allah, Dagne Wegary, P.H. H. Zaidi, Kenneth J. Boote, Dil Rahut, and Olaf Erenstein. 2018. "Potential Benefits of Drought and Heat Tolerance for Adapting Maize to Climate Change in Tropical Environments." Climate Risk Management 19: 106-19. https://doi.org/10.1016/j.crm.2017.10.001.

TWI2050. 2018. "TWI2050 Report: Transformations to Achieve the Sustainable Development Goals Report 2018 - IIASA." Laxenburg, Austria. http://pure.iiasa.ac.at/15347.

Ugur, Mehmet, and Arup Mitra. 2017. "Technology Adoption and Employment in Less Developed Countries: A Mixed-Method Systematic Review." World Development. https://doi.org/10.1016/j.worlddev.2017.03.015.

Wang, Shuhong, Yuqing He, and Malin Song. 2021. "Global Value Chains, Technological Progress, and Environmental Pollution: Inequality towards Developing Countries." Journal of Environmental Management 277. https://doi.org/10.1016/j.jenvman.2020.110999.

Weindl, I., H. Lotze-Campen, A. Popp, C. Müller, P. Havlík, M. Herrero, C. Schmitz, and S. Rolinski. 2015. "Livestock in a Changing Climate: Production System Transitions as an Adaptation Strategy for Agriculture." Environmental Research Letters 10 (9). https://doi.org/10.1088/17489326/10/9/094021.

Wertheim-Heck, Sigrid C.O., Sietze Vellema, and Gert Spaargaren. 2015. “Food Safety and Urban Food 
Markets in Vietnam: The Need for Flexible and Customized Retail Modernization Policies." Food Policy 54. https://doi.org/10.1016/j.foodpol.2015.05.002.

Wiggins, Steve, Johann Kirsten, and Luis Llambí. 2010. "The Future of Small Farms." World Development. https://doi.org/10.1016/j.worlddev.2009.06.013.

Willett, Walter, Johan Rockström, Brent Loken, Marco Springmann, Tim Lang, Sonja Vermeulen, Tara Garnett, et al. 2019. "Food in the Anthropocene: The EAT-Lancet Commission on Healthy Diets from Sustainable Food Systems." The Lancet, January. https://doi.org/10.1016/S01406736(18)31788-4.

World Bank. 2008. World Development Report 2008: Agriculture for Development. The World Bank.

-- - 2010. "World Development Report 2010 : Development and Climate Change." Washington D.C., USA.

---. 2020. World Development Report 2020 - Global Value Chains: Trading for Development. World Bank Group. Washington DC, USA: World Bank Group. https://www.worldbank.org/en/publication/wdr2020.

- - . 2021. "World Development Report 2021 Data for Better Lives." Washington D.C., USA.

Wossen, T., and T. Berger. 2015. "Climate Variability, Food Security and Poverty: Agent-Based Assessment of Policy Options for Farm Households in Northern Ghana." Environmental Science and Policy 47: 95-107. https://doi.org/10.1016/j.envsci.2014.11.009.

Wossen, Tesfamicheal, Tahirou Abdoulaye, Arega Alene, Shiferaw Feleke, Jacob Ricker-Gilbert, Victor Manyong, and Bola Amoke Awotide. 2017. "Productivity and Welfare Effects of Nigeria's eVoucher-Based Input Subsidy Program." World Development 97: 251-65.

Yadav, O.P., B.M. Prasanna, P. Yadava, S.L. Jat, D. Kumar, B.S. Dhillon, I.S. Solanki, and J.S. Sandhu. 2016. "Doubling Maize (Zea Mays) Production of India by 2025-Challenges and Opportunities." Indian Journal of Agricultural Sciences 86 (4): 427-34.

Yalew, A.W., G. Hirte, H. Lotze-Campen, and S. Tscharaktschiew. 2018. "Climate Change, Agriculture, and Economic Development in Ethiopia." Sustainability (Switzerland) 10 (10). https://doi.org/10.3390/su10103464.

Yamano, Takashi, Aminou Arouna, Ricardo A. Labarta, Zenaida M. Huelgas, and Samarendu Mohanty. 2016. "Adoption and Impacts of International Rice Research Technologies." Global Food Security. https://doi.org/10.1016/j.gfs.2016.01.002.

Yigezu, A Yigezu, and J H Sanders. 2012. "Introducing New Agricultural Technologies and Marketing Strategies: A Means for Increasing Income and Nutrition of Farm Households in Ethiopia." African Journal of Food, Agriculture, Nutrition and Development 12 (5): 6365-84.

Yigezu, Yigezu A., Corinne E. Alexander, Paul V. Preckel, D. E. Maier, L. J. Mason, C. Woloshuk, J. Lawrence, and D. J. Moog. 2010. "Economics of Integrated Insect Management in Stored Corn." Journal of Economic Entomology 103 (5): 1896-1908. https://doi.org/10.1603/EC09390.

Yigezu, Yigezu Atnafe, Amin Mugera, Tamer El-Shater, Aden Aw-Hassan, Colin Piggin, Atef Haddad, Yaseen Khalil, and Stephen Loss. 2018. "Enhancing Adoption of Agricultural Technologies Requiring High Initial Investment among Smallholders." Technological Forecasting and Social Change 134 
(September): 199-206. https://doi.org/10.1016/J.TECHFORE.2018.06.006.

Zerfu Gurara, Daniel, and Dawit Birhanu. 2012. "Large Scale Land Acquisitions in Africa." African Development Bank. Africa Economic Brief 3 (5) May 2012.

Zhang, Qian, Zhongxiao Sun, and Wei Huang. 2018. "Does Land Perform Well for Corn Planting? An Empirical Study on Land Use Efficiency in China." Land Use Policy 74. https://doi.org/10.1016/j.landusepol.2017.10.032.

Zhou, Yuan, and John Staatz. 2016. "Projected Demand and Supply for Various Foods in West Africa: Implications for Investments and Food Policy." Food Policy. https://doi.org/10.1016/j.foodpol.2016.04.002. 